experiments, which foreshadows the approaching crisis in the philosophy of experimentation. Is the laboratory or the field the right place for an experiment, and how far should research be operational ?

Several of the papers are in the nature of surveys of particular fields: Wolfowitz on non-parametric inference, Doob on time-series and harmonic analysis, and Feller on stochastic processes. Although written four years ago (a long time on the current statistical time-scale), they are very useful and must have done much to further the objects of the symposium.

M. G. KendaLL

$$
101=
$$

\section{ELECTRICAL ENGINEERS' HANDBOOK}

\section{Standard Handbook for Electrical Engineers}

By Archer E. Knowlton (Editor-in-Chief) and R. M. Shoop (Assistant Editor). Eighth edition. Pp. xi+ 2311. (New York and London: McGraw-Hill Book Co., Inc., 1949)

$\mathrm{T}$ "Stand ro Handbook for Electrical Engin. eers' first fublished by the McGraw Hill Book Co in 19 7, hws reached its eighth edition. This worly has occupied a place on the bookshelves of eledurical engineers throughout the world for so long a period that it has, indeed, established its claim to its title.

The subject-matter of the book, which comprises a little more than 2,300 pages, is divided into twentysix sections covering the whole range of electrical technology in power and telecommunication applications. It is stated in the preface that it was considered that the previous edition had reached the limiting practicable dimensions and that, in preparing the present edition, pressure had been put on the contributors to condense their material to a point just short of incompleteness or ambiguity. Extensive sampling of the various sections suggests that a very satisfactory result has been achieved. In general, the salient points are treated at sufficient length to be readily intelligible, and references to the literature indicate sources of detailed information on specific points.

A number of subjects of comparatively recent development now constitute complete sections or sub-sections. For example, under Section 26, "Electro-physics", there is given a very satisfactory outline of nuclear energy and radioactivity, while radio, radar and carrier communication together constitute the subject-matter of Section 24 . Nielectric heating and eddy-current heating are treated in the section on "Flectric Heating and Welding", and under "Electricity in Transportation" there is a sub-section dealing with the electrical equipment of aircraft. Electrical servo-mechanisms form a sub-section under "Industrial and Commercial Power"; but it is perhaps a little remarkable that only six pages should be allocated to this important topic. The properties of the newer dielectric and magnetic materials are summarized satisfactorily in Section 4. There does not, however, appear to be any information on ferrites, and there is no indexed reference to nonlinear resistors other than carbon.

The handbook is, of course, a guide to American practice, and numerous tables, data and references which are of the utmost value to the reader concerned with A merican installations are of less direct utility to the average British user. Very far-reaching, although in many instances comparatively slight, differences result from the difference between the American standard supply frequency $(60 \mathrm{c.} / \mathrm{s}$.) and the British $(50 \mathrm{c.} / \mathrm{s}$.). The numerous references to the specifications of the American Standards Association and the American Society for Testing Materials are again of less direct value to the British reader. References to text-books and scientific publications are, of course, predominantly American; but contributions from other countries are well represented in most sections, and the bibliographic material has been judiciously selected.

There are, not unnaturally, noticeable differences between sections in the rigour with which obsolescent material has been pruned and the efficiency with which new material has been grafted. On the whole, however, the revision has been remarkably well done, and the "Handbook" remains one of the most valuable sources of summarized information and reference on electrical matters. The new edition maintains in the fullest sense the high standard set by its predecessors.

J. Greia

\section{TREATISE OF ZOOLOGY

$$
|H|=
$$

\section{Traité de zoologie}

Anatomie, systématique, biologie. 1 publié sous Ia direction de Prof. Pierre-P. A assé. Tome 6: Onychophores, tardigrate, orth morphes, chélicérates Pp. viii + 980. (Paris : Masson et Cie, 1949.) 5,000 Prancs.

\section{Traité de pologie}

Ayatgm f,- systématique, biologie. Publié sous la dfrecton de Prof. Pierre-P. Grassé. Tome 9 : Insectes; płéontologie, géonémie, aptérygotes, ephéméroptères, odonatoptères, blattoptéroïdes, orthoptéroïdes, dermaptéroïdes, coléoptères. Pp. viii + 1118. (Paris: Masson et Cie, 1949.) 4,500 francs.

$\mathrm{N}$ reviewing the first volume to be produced of this I new "Treatise of Zoology", actually Volume 11 in the series (see Nature, February 19, p. 269), it was pointed out that in publishing a series of large volumes there is a danger that the earlier ones may become out of date before the later ones appear. The publishers seem to be doing their best to avoid this, since two further volumes are now to hand, and another, Volume 15, on birds, is announced to appear during the present year. It may be said at the outset that the present volumes fully maintain the high standard of printing and illustrating of their predecessor, and the coloured plates in both are very good. The practice of including a treatment of fossil groups in their systematic position, although from the nature of the material it cannot be so full as in the case of living groups, and of discussing their relationship is to be commended since it gives a more satisfying picture of the animal kingdom as a whole than dealing with them in separate and unrelated publications. It is a pity that the size of the animal illustrated is not indicated more consistently, as it is in the Coleoptera, particularly in the more unusual and bizarre forms.

Volume 6 of the series, a book of 980 pages, contains 719 text figures, 46 of which are in half-tone and the remainder in line block; five of the latter are reinforced with colour, and, in addition, there are four coloured plates. Its contributors are M. André, 